Krzysztof OŚCIŁOWSKI O.S.P.P.E. (Kraków, WSD OO. Paulinów)

\title{
ROLA STARSZYCH W WYBRANYCH STAROŻYTNYCH REGULACH MONASTYCZNYCH
}

Starożytne reguły monastyczne określają zasady, które obowiązują mnichów należących do wspólnoty monastycznej. Znajdziemy w nich różne przepisy, bądź ogólne, bądź szczegółowe, które regulują życie mnicha i całej wspólnoty monastycznej. W odniesieniu do osób, które przebywają w monasterium, najwięcej norm dotyczy przełożonych, opatów oraz ojców pełniących określone funkcje we wspólnocie. Są także przepisy wskazujące, jak należy postępować w różnych okolicznościach życia codziennego.

W wielu regułach spotykamy się z nazwą, „starsi”. Autorzy poszczególnych reguł na ich określenie używają terminów: senior, maior, prior lub senex w regułach łacińskich, bądź w tekstach reguł zachowanych po łacinie, oraz $\pi \rho \varepsilon \sigma-$

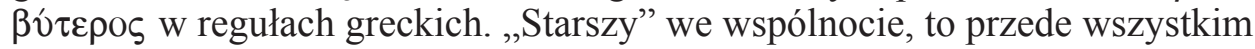
osoba, która wyróżnia się zaletami osobistymi, budzi zaufanie, jest przykładem wzorowego życia ascetycznego, znająca zasady tego życia we wspólnocie klasztornej. ,Starszy” w regułach monastycznych, to zarówno osoba dojrzała duchowo, jak i taka, która osiągnęła już wiek sędziwy. Ze względu autorytet duchowy, moralny i ascetyczny lub z racji wieku starsi „mieli w klasztorze pewna pozycję" i spełniali we wspólnocie określone funkcje. Przedstawimy teraz ich rolę i zadania we wspólnocie klasztornej w odniesieniu jedynie do wybranych reguł. Trzeba tutaj bowiem zauważyć, że w niektórych kodyfikacjach monastycznych o „starszych” nie ma w ogóle mowy np. w krótkiej regule św. Augustyna (Praecepta). W niniejszym opracowaniu uwzględnimy Regułę Pachomiusza, Reguły Dłuższe i Krótsze Bazylego Wielkiego, wczesne reguły monastyczne w Galii (Druga Regutę Ojców, Regutę Makarego, Regute Wschodnia), Regułę Mistrza i Regutę Benedykta.

${ }^{1}$ Pachomius, Praecepta 17, PL 23, 70: „maioribus monasterii, qui alicuius nominis sunt”. Tekst Reguły Pachomiusza w łacińskim przekładzie św. Hieronima, zawarty w PL 23, 65-90, oprócz wstępu (Praefatio) składa się z czterech części: Praecepta (Przykazania), Praecepta et instituta (Przykazania i postanowienia), Praecepta atque iudicia (Przykazania i orzeczenia) i Praecepta ac leges (Przykazania i prawa). Jej polski przekład zob. w ŹM 11 (Pachomiana latina), Tyniec - Kraków 1996, 123-172 (Przedmowa - thum. A. Bober; Przykazania i postanowienia - thum. M. Starowieyski; Przykazania i orzeczenia - thum. M. Starowieyski; Przykazania i prawa - thum. M. Starowieyski. 
1. Reguła i polecenia starszych. W regułach monastycznych znajdujemy często zapisy, które mówią wprost o konieczności przestrzegania reguły klasztoru i „poleceń starszych”. Oprócz poleceń starszych funkcjonują również określenia ,przykład starszych” i ,rady starszych”. Nieprzestrzeganie ich wiąże się z odpowiednią kara, a przy uporze mnicha kara ta, to nawet chłosta czy usunięcie ze wspólnoty. W Praecepta atque iudicia pachomiańskiej Reguly czytamy:

„Ci, którzy gardzą przykazaniami przełożonych (praecepta maiorum) i zasadami, którymi rządzi się klasztor (regula monasterii) - a one są z ustanowienia Bożego - i którzy lekceważą rady starszych (consilia seniorum) zostaną ukarani wedle zasad ustanowionych, aż się poprawią"2.

Kopię tego przykazania spotykamy w Regule Wschodniej ${ }^{3}$. Fakt ten świadczy o tym, że autorzy reguł później powstałych znali te wcześniejsze, wzorowali się na nich, a nawet - jak widać - kopiowali je w dosłownym brzmieniu. Zachętę do przestrzegania rad czy przykazań „starszych” i nie lekceważenia ich także przez przełożonego spotykamy w Praecepta et instituta Reguly Pachomiusza:

„Przełożony niech nie lekceważy starców, aby mógł zawsze badać swe myśli ${ }^{4}$ oraz gdy sądzi, niech idzie za przykazaniami starców i za Prawem Bożym, które jest przepowiadane po całym świecie"s.

Benedykt z Nursji w swojej Regule również wspomina o zachowaniu wspólnej reguły klasztoru lub tego, do czego wzywa przykład starszych (exempla maiorum). Mówi o tym, gdy przedstawia dwunastostopniową skalę pokory: mnich, który nie robi nic więcej poza zachowaniem reguły i zastosowaniem się do przykładu starszych, zostaje postawiony na ósmym stopniu pokory ${ }^{6}$. Łamanie reguły i poleceń starszych (praecepta seniorum) jest powodem do dyskretnego upomnienia braterskiego przez przełożonych (seniores). W przypadku dalszej niesubordynacji mnicha upomnienie jest publiczne wobec pozostałych braci, a jeśli i ono nie przynosi poprawy, grozi mu wyłączenie ze wspólnoty lub kara cielesna ${ }^{7}$. Brat wyłączony ze wspólnoty nie zostaje jed-

2 Pachomius, Praecepta atque iudicia 8 (167), PL 23, 87: „Qui contemnunt praecepta maiorum et regulas monasterii, quae Dei praecepto constitutae sunt, et parvi pendunt seniorum consilia, corripientur iuxta ordinem constitutum, donec corrigantur”, tłum. ŹM 11, 167.

${ }^{3}$ Por. Regula Orientalis 19, SCh 298, 476, tłum. K. Bielawski, ŹM 3, 75.

${ }^{4}$ Pachomius, Praecepta et instituta 159 (50), PL 23, 85: „Ne senes negligat: semper diiudicet cogitationes suas”. Takie thumaczenie znajdziemy w przypisie (a), choć w tekście mamy: „Ne se negligat, ut semper diiudicet cogitationes suas", ŹM 11, 163.

5 Tamże 159 (52), PL 23, 85: „Quando iudicat, sequatur praecepta maiorum et legem Dei, quae in toto orbe praedicata est", ŹM 11, 163.

${ }^{6}$ Por. Benedictus, Regula 7, 55, CSEL 75, 49: „Octabus humilitatis gradus est, si nihil agat monachus, nisi quod communis monasterii regula vel maiorum cohortatur exempla”, tłum. T.M. Dąbek - B. Turowicz, ŹM 40, 416.

${ }^{7}$ Por. tamże 23, 1-5, CSEL 75, 78-79, ŹM 40, 438. 
nak pozostawiony sam sobie. Opat wysyła do niego braci starszych i mądrych (seniores sapientes fratres), zwanych ,sympektami” (senpectae), których celem jest pocieszanie i nakłanianie do pokornej poprawy ${ }^{8}$.

2. Udzial w liturgii, modlitwie, katechezie. Pachomiusz w swojej Regule (Praecepta) wskazuje na przywileje starszych w czasie zgromadzenia liturgicznego, w którym są zrównani z przełożonymi. W niedzielę i na zgromadzeniu modlitewnym, gdy jest sprawowana Msza św., odmawiać moga psalmy jedynie przełożeni i starsi (maiores). W trakcie nabożeństwa wszyscy muszą być obecni i nikt nie może opuszczać zgromadzenia bez pozwolenia starszego. Gdyby ktoś z braci był nieobecny lub też wyszedł ze spotkania modlitewnego, zostanie ukarany 9 .

Szczególna funkcja starszego we wspólnocie dotyczy także katechezy. Obowiązek wygłaszania katechezy dla mnichów spoczywał na przełożonym domu lub zwierzchniku klasztoru. Każdego tygodnia przełożony wygłaszał trzy katechezy, ale głosili je również starsi, a ich przemowę autor reguły nazywa „nakazami starszych"10.

3. Rola starszych w formacji monastycznej nowicjuszy. Ze względu na doświadczenie, długość przebywania we wspólnocie monastycznej i osobiste cechy, starsi mieli wpływ na formację braci w klasztorze, który był dwojaki: bądź przez pełnienie funkcji formatora, wyznaczonego przez przełożonego, bądź też przez dobry przykład, do którego starsi byli szczególnie zobowiązani.

O pierwszym wspomina Reguła Benedykta, która nakłada to odpowiedzialne zadanie formacyjne na seniora - starszego mnicha, który został wyznaczony do sprawowania opieki nad nowicjuszami. Tenże starszy winien posiadać wyjątkową zaletę, która została określona jako „uzdolnienie do pozyskania dusz" (qui abtus sit ad lucrandas animas) ${ }^{11}$. Zadaniem tego starszego mnicha będzie nadzorowanie nowicjuszy, rozpoznanie czy dany nowicjusz „,prawdziwie szuka Boga, jest gorliwy w Bożym oficjum, w posłuszeństwie i w znoszeniu upokorzeń"12 i „czy wie, czego się podejmuje"13.

O dawaniu dobrego przykładu przez starszych nowo wstępującym do klasztoru mówią z kolei Reguły Krótsze Bazylego. Bazyli dzieli ich na tych w pełni sprawnych fizycznie, oraz na tych o słabym zdrowiu. Starsi, którzy są

${ }^{8}$ Por. tamże 27, 1-3, CSEL 75, 82-83, ŹM 40, 442.

${ }^{9}$ Por. Pachomius, Praecepta 17-19, PL 23, 70, ŹM 11, 132.

${ }^{10}$ Por. tamże 21-23, PL 23, 70, ŹM 11, 132.

${ }^{11}$ Benedictus, Regula 58, 6, CSEL 75, 134, ŹM 40, 481.

${ }^{12}$ Tamże 58, 7, CSEL 75, 134: „Et sollicitudo sit si revera Deum quærit, si sollicitus est ad opus Dei, ad oboedientiam, ad obprobria", ŹM 40, 481.

${ }^{13}$ Tamże 58, 12, CSEL 75, 135: „Et post sex mensuum circuitum legatur ei regula, ut sciat, ad quod ingreditur", ŹM 40, 482; por. B. Rollin, Jak żyć reguła św. Benedykta. Komentarz do Reguły, Kraków 2005, 179. 
mocni fizycznie będą przykładem w swojej gorliwości i spełnianiu dobrych uczynków. Natomiast starsi, którzy są słabi na ciele, będą przykładem miłości do Boga i Jego obecności w ich życiu, co wyrażać się będzie w pogodnym obliczu odzwierciedlającym ich stan duszy. Oznakami owej miłości, będą te wymienione przez św. Pawła w 1 Kor 13, 4-8 ${ }^{14}$.

4. Rady starszych. W ważniejszych sprawach klasztoru opat zwoływał wszystkich braci, aby wysłuchać ich rady. Potem sam podejmował decyzję, którą uważał za słuszną. W przypadku spraw mniejszej wagi nie musiał już radzić się wszystkich, ale jedynie korzystał z rady starszych (consilium seniorum) ${ }^{15}$.

5. Pozwolenie starszych. Starszy mógł udzielać pozwoleń poszczególnym mnichom, zwalniając ich przy tym z zachowania przepisów reguły. Takie pozwolenie (concessio maioris) dotyczyło chociażby zabierania ze sobą lnianego płaszcza w czasie wyjścia do pracy ${ }^{16}$, którego noszenia reguła zabraniała $\mathrm{w}$ klasztorze na zgromadzeniach modlitewnych i w czasie prac na polu ${ }^{17}$. Innym przywilejem starszego było udzielenie zgody (imperium maioris) na siedzenie $\mathrm{w}$ trakcie pracy ${ }^{18}$. Starszy sprawował pieczę nad pracującymi braćmi, dlatego też reguła zachęca ich, aby byli ochoczo poddani starszym w czasie tej czynności ${ }^{19}$. Gdy zaś praca ma miejsce poza klasztorem starszy posiada prawa przełożonego ${ }^{20}$. Kolejnym pozwoleniem starszego (arbitrium maioris), była możliwość strzyżenia głowy przez mnicha ${ }^{21}$. Reguła Wschodnia podaje, że bez pozwolenia starszych i ich rady szafarz niczego nie przyjmuje z tego, co przyniesiono do klasztoru, ani niczego nie wydaje ${ }^{22}$. Podobne pozwolenie opata lub starszych dotyczy furtiana, który niczego nie może przyjąć spoza klasz-

${ }^{14}$ Por. Basilius Magnus, Regulae brevius tractatae 200, PG 31, 1215-1216, thum. J. Naumowicz, ŹM 6, 353.

${ }^{15}$ Por. Benedictus, Regula 3, 1-13, CSEL 75, 27-29, ŹM 40, 399-400, spec. 3, 12, CSEL 75, 28, ŹM 40, 400.

${ }^{16}$ Por. Pachomius, Praecepta 61, PL 23, 75: „Nemo palliolum lineum tollet secum vadens ad operandum, nisi forte concessione maioris”, ŹM 11, 142.

${ }^{17}$ Por. tamże 101, PL 23, 78: „Nullus vadat ad collectam vel ad vescendum habens galliculas in pedibus, vel palliolo lineo invittatus, sive in monasterio, sive in agris", ŹM 11, 148.

${ }^{18}$ Por. tamże 62, PL 23, 75: „Operans non sedebit sine maioris imperio”, ŹM 11, 142.

${ }^{19}$ Por. Pachomius, Praecepta ac leges 179 (3), PL 23, 87-88: ,[...] libenter maioribus subiiciantur", ŹM 11, 170.

${ }^{20}$ Por. tamże 189 (13), PL 23, 89: „Maiores qui cum fratribus mittuntur foras, quandiu ibi fuerint, habebunt ius praepositorum, et eorum cuncta regentur arbitrio", ŹM 11, 172. Kopię tego przykazania znajdziemy w Regula Orientalis 20, SCh 298, 476, ŹM 3, 75.

${ }^{21}$ Por. Pachomius, Praecepta 96 (97), PL 23, 78: „Nullus attondeat caput absque maioris arbitrio", ŹM 11, 147.

${ }^{22}$ Por. Regula Orientalis 25, 2, SCh 298, 480: „Nihil suscipiens nec quicquam tradens sine auctoritate vel seniorum consilio", ŹM 3, 77. 
toru i przekazać braciom, nawet wiadomości ${ }^{23}$. Ponadto furtian o wszystkim informuje starszych ${ }^{24}$. Reguła zaś Benedykta ma większe zaufanie do furtiana, bo czyni nim brata starszego i mądrego (senes sapiens), podkreślając przy tym wyraźnie jego dojrzały wiek (maturitas) ${ }^{25}$. W Regule Wschodniej została też sformułowana zasada ogólna:

„bez pozwolenia i rady starszych niech żaden brat niczego nie czyni, niczego nie przyjmuje, niczego nie daje, ani też nigdy i nigdzie nie idzie" ${ }^{26}$.

Swoim starszym więc należy okazać posłuszeństwo ${ }^{27}$.

6. Sprawowanie nadzoru przez starszych. W Regule św. Benedykta zadaniem starszych jest sprawowanie nadzoru nad pozostałymi braćmi. W godzinach przeznaczonych na lekturę jeden lub dwóch starszych (seniores), którzy zostali do tego celu wyznaczeni będą obchodzić cały klasztor i sprawdzać, czy bracia właściwie wykorzystują czas na czytanie ${ }^{28}$.

Wyznaczeni jeden lub dwóch braci starszych (seniores) sprawują nadzór, troskę o zachowanie karności (disciplina) przez wszystkich braci podczas wspólnego posiłku. Opat zazwyczaj jest nieobecny na posiłku ze wspólnotą, ponieważ ma obowiązek spożywania go z gośćmi i pielgrzymami ${ }^{29}$.

Reguła Wschodnia mówi o dwóch starszych, którzy bądź podczas obecności opata, bądź podczas jego nieobecności, będą odpowiedzialni za karność wszystkich braci i za wszelkie potrzeby klasztoru. Jeden powinien być zawsze obecny w klasztorze i pomagać opatowi w przyjmowaniu przybywających braci, troszczyć się o potrzeby klasztoru i o wszystko, co jest konieczne w życiu codziennym i mniszym w klasztorze. Drugi zaś powinien przebywać

${ }^{23}$ Por. tamże 26, 5, SCh 298, 482: „Si quid vero cuicumque de fratribus missum mandatumque fuerit, nihil ad ipsum perveniat priusquam abbati vel senioribus indicetur”, ŹM 3, 78.

${ }^{24}$ Por. tamże 27, 8, SCh 298, 484: „Haec observabit custos ianuae, referens omnia, sicut superius scriptum est, adnuntians senioribus", ŹM 3, 78.

${ }^{25}$ Por. Benedictus, Regula 66, 1, CSEL 75, 155: „Ad portam monasterii ponatur senes sapiens, qui sciat accipere responsum et reddere et cuius maturitas eum non sinat vacari”, ŹM 40, 496.

${ }^{26}$ Regula Orientalis 31, 1-3, SCh 298, 488: „Sine seniorum verbo et auctoritate nullus frater quicquam agat, necque accipiat aliquid neque det, neque usquam prorsus procedat”, ŹM 3, 79.

${ }^{27}$ Por. tamże 30, 1, SCh 298, 486, ŹM 3, 79.

${ }^{28}$ Por. Benedictus, Regula 48, 17-18, CSEL 75, 117-118, ŹM 40, 469. Reguła Benedyktyńska określała czas na pracę i czas na czytanie. Czas na lekturę w okresie od Wielkanocy do 1 października: od czwartej godziny do seksty; od 1 października do początku Wielkiego Postu czytanie trwa do godziny drugiej, także możliwość po posiłku lektury lub odmawiania psalmów; w okresie Wielkiego Postu czytanie zaczyna się rano i trwa do godziny trzeciej. W Wielkim Poście każdy z braci otrzymuje jedną książkę z biblioteki, którą jest zobowiązany przeczytać w całości (por. Benedictus, Regula 48, ŹM 40, 468-469).

${ }^{29}$ Por. tamże 56, 1-3, CSEL 75, 131: „Mensa abbatis cum hospitibus et peregrinis sit semper. Quotiens tamen minus sunt hospites, quos vult de fratribus vocare, in ipsius sit potestate. Seniore tamen uno aut duo semper cum fratribus dimittendum propter disciplinam”, ŹM 40, 479. 
z braćmi, wychodzić z nimi do wspólnej pracy i czuwać ich nad karnością. Tymi obowiązkami dwaj starsi będą się wymieniaćc ${ }^{30}$.

7. Napomnienia i karcenie braci przez starszych. W niektórych regułach zadaniem starszych jest napominanie i karcenie braci. Reguła Ojca Makarego zawiera krótki, ale konkretny w treści zapis w formie trzech imperatywów: Nakaz starszego przyjmuj jako zbawienny. Wykonuj każde zadanie bez szemrania. Nie sprzeciwiaj się wydanemu rozporządzeniu ${ }^{31}$. Reguła ta czyni dalej wskazanie, aby został osądzony i skarcony przez starszego taki brat, który szemrze, jest kłótliwy, albo objawia oporną wolę wobec poleceń. Zostanie on ukarany stosownie do wykroczenia, które popełnił ${ }^{32}$. Gdyby jednak częste napomnienia nie skutkowały i nie przynosiły poprawy, taki mnich będzie zajmował ostatnie miejsce we wspólnocie. A gdy nadal poprawa nie nastapi, będzie traktowany jak obcy, zgodnie ze słowami Pana: ,jak poganin i celnik” (Mt 18, 17) ${ }^{33}$. Podobne stwierdzenie znajdziemy w Regule Wschodniej: ten, kto zostanie przyłapany na kłótni lub przeciwstawia się rozkazowi starszego, zostanie odpowiednio ukara$n^{34}$. O upomnieniu braterskim starszego, mającym na celu poprawę brata, który kroczy „,szeroką drogą na zatracenie” czyni wzmiankę także Reguła Mistrza ${ }^{35}$.

8. Szczególne prawa starszych wobec przełożonych. Reguła przyznawała starszym określone działania w stosunku do osób, które zajmowały ważne stanowiska we wspólnocie, na czele z przełożonym. W Regule Pachomiusza (Praecepta) czytamy:

„Gdyby przełożony lub ekonom przez jedną noc spał bez braci poza domem, a później po odbyciu pokuty, wróciłby do społeczności braci, nie będzie mu dozwolone wejść do domu i powrócić na swoje miejsce bez pozwolenia starszego"36.

${ }^{30}$ Por. Regula Orientalis 2, SCh 298, 464, ŹM 3, 68-69.

${ }^{31}$ Por. Regula Macarii 4, 1-3, SCh 297, 374: „Praeceptum senioris ut salutem suscipias. Non murmurando ullam operam facias. Non responsionem contra praeceptum usurpes”, thum. K. Bielawski, ŹM 3, 57.

${ }^{32}$ Por. tamże 12, 1-3, SCh 297, 376-378, ŹM 3, 58.

${ }^{33}$ Por. Regula Patrum secunda 7, 43-45, SCh 297, 282: „Qui vero saepius correptus non se emendaverit, novissimus in ordine stare iubeatur. Qui nec sic quidem emendaverit, extraneus habeatur, sicut Dominus dixit: «Sit tibi sicut ethnicus et publicanus»”, ŹM 3, 55; zob. też Regula Macarii 17, 1-4, SCh 297, 380, ŹM 3, 59.

${ }^{34}$ Por. Regula Orientalis 14, SCh 298, 470: „Si inventus fuerit unus e fratribus aliquid per contentionem agens uel contradicens maioris imperio, increpabitur iuxta mensuram peccati sui", ŹM 3, 72. Norma ta jest kopią pachomiańskich Praecepta et instituta 150 (9), PL 23, 83, ŹM 11, 158, podobnie jak następna Regula Orientalis 15, SCh 298, 470, ŹM 3, 72 kopią pachomiańskich Praecepta et instituta 151 (10), PL 23, 83, ŹM 11, 158.

${ }^{35}$ Por. Regula Magistri 7, 37, SCh 105, 388, ŹM 40, 120.

${ }^{36}$ Pachomius, Praecepta 137, PL 23, 81-82: „Praepositus domus et dispensator si una nocte absque fratribus dormierit: et postea acta poenitudine ad conventum venerit fratrum, non ei permittetur, ut introeat domum, aut stet in ordine suo absque maioris imperio", ŹM 11, 132. 
O tym, kto może upomnieć przełożonego, gdy ten popełni błąd, mówią także Reguty Dluższe Bazylego Wielkiego:

„Prawo udzielania napomnień winno przysługiwać tym, którzy wyróżniają się wiekiem i roztropnością we wspólnocie (czyli starszym - K.O.)"37.

\section{Relacje między starszymi a młodszymi we wspólnocie klasztornej.} Przede wszystkim obowiązuje zasada, która wskazana jest wśród narzędzi dobrych uczynków w Regule Benedykta, że „starszych należy szanować (seniores venerare), młodszych miłować (iuniores diligere)" ${ }^{\prime 38}$, powtórzona również w innym miejscu:

„Młodsi (iuniores) mają szanować swoich starszych (priores), a starsi (priores) niech kochają swoich młodszych (minores) ${ }^{39}$.

Ten wzajemny szacunek będzie się wyrażał np. w rozmowie. Bracia nie zwracają się do siebie po imieniu, ale:

„Starsi (priores) nazywają młodszych (iuniores) braćmi, a młodsi (iuniores) starszych (priores) wielebnymi ojcami (nonni, quod intellegitur paterna reverentia). Podczas spotkania młodszy (iunior) prosi starszego (prior) o błogosławieństwo. Gdy starszy (maior) nadejdzie, młodszy (minor) ma powstać i ustapić mu miejsca, aby usiadł. I niech sam nie siada, póki go starszy (senior) nie zaprosi” ${ }^{40}$.

„Wszyscy młodsi (iuniores) mają się stosować do życzeń starszych (priores) z całą miłością i gorliwością"41.

10. Starsi i młodsi w dormitorium. Spoczynek nocny braci wiąże się z obecnością starszych (seniores). Reguła św. Benedykta zaleca, jeśli to jest możliwe, spanie w jednej celi, choć każdemu przysługuje osobne łóżko. Gdy nie ma takiej możliwości, wówczas mnisi będą spali po dziesięciu lub dwudziestu wraz ze starszymi. Zadaniem starszych będzie czuwanie nad pozosta-

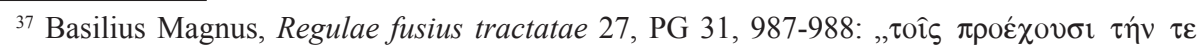

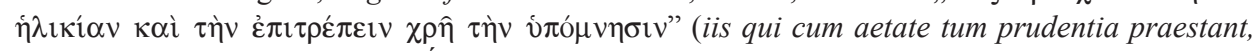
danda est admonendi potestas", ŹM 6, 126.

${ }^{38}$ Benedictus, Regula 4, 70.71, CSEL 75, 34, ŹM 40, 405.

${ }^{39}$ Tamże 63, 10, CSEL 75, 147: „Iuniores igitur priores suos honorent, priores minores suos diligant", ŹM 40, 490.

${ }^{40}$ Tamże 63, 12.15-16, CSEL 75, 147: „sed priores iuniores suos fratrum nomine, iuniores autem priores suos nonnos vocent, quod intelligitur paterna reverentia"; 63, 15, CSEL 75, 147: „Ubicumque autem sibi obviant fratres, iunior priorem benedictionem petat”; 63, 16, CSEL 75, 147: „transeunte maiore minor surgat et det ei locum sedendi. Nec praesumat iunior consedere, nisi ei praecipiat senior suus", ŹM 40, 490.

${ }^{41}$ Tamże 71, 4, CSEL 75, 161: ,de cetero omnes iuniores prioribus suis omni caritate et sollicitudine oboediant”, ŹM 40, 501. 
łymi. Reguła jest bardzo precyzyjna i podaje również sposób ułożenia łóżek w celi. Łóżka młodszych braci (adulescentiores) nie powinny stać obok siebie, lecz rozdzielone posłaniami starszych (seniores) ${ }^{42}$.

11. Starsi wiekiem, słabi. Osoby $\mathrm{w}$ wieku podeszłym, zwłaszcza ze względu na słabości i ułomności, które z nim się wiążą mają pewne przywileje. Reguła Pachomiusza w Praecepta daje możliwość, za pozwoleniem ojca klasztoru, osobom w podeszłym wieku i chorym, spania w zamkniętej celi ${ }^{43}$. Mnisi zgodnie z regułą pachomiańską spali w otwartych celach.

Z kolei Reguła Benedykta wyraźnie podkreśla, że przepisy dotyczące pożywienia starszych wiekiem nie obowiązują i mogą oni spożywać posiłki przed ustalonymi godzinami. Te same prawa mają także dzieci ${ }^{44}$. W innym miejscu Reguła staje w obronie starszych wiekiem i dzieci:

„Jeśli ktoś pozwoli sobie bez upoważnienia opata upominać braci starszych (in fortiori aetate) albo karać dzieci (infantes) bez umiarkowania, ma być według Reguly ukarany"45.

Z wyżej przedstawionych zagadnień wynika, że starsi pełnili we wspólnotach klasztornych ważną rolę. Dotyczyła ona różnych wymiarów życia klasztornego i realizacji postanowień reguły na co dzień. Każda ze wspomnianych wybranych reguł podkreśla rozmaite obowiązki i działania starszych. Często są one podobne, ale są i takie, które cechują się swoistą odrębnością. Pośród nich wymieniliśmy zadania starszych w liturgii, zgromadzeniu modlitewnym, w głoszeniu katechezy, w formacji, szczególnie nowicjuszy. Starsi udzielają rad, pozwoleń, napominają braci, ale i przełożonych, czasami karcą. Są przykładem dla innych. Dobrze komponują się z młodymi braćmi we wspólnocie. A starsi, osoby w wieku podeszłym i słabi, doznają troski ze strony wspólnoty.

${ }^{42}$ Por. tamże 22, CSEL 75, ss. 77-78, ŹM 40, 437.

${ }^{43}$ Por. Pachomius, Praecepta 107, PL 23, 79: „Clausa cella nullus dormiat, nec habebit cubiculum quod claudi possit, ni forte aetati alicuius vel infirmitati Pater monasterii concesserit”, ŹM 11, 149.

${ }^{44}$ Por. Benedictus, Regula 37, 1-3, CSEL 75, 97: „Licet ipsa natura humana trahatur ad misericordiam in his aetatibus, senum videlicet et infantum, tamen et regulae auctoritas eis prospiciat. Consideretur semper in eis invecillitas et ullatenus eis districtio regulae teneatur in alimentis, sed sit in eis pia consideratio et praeveniant horas canonicas", ŹM 40, 455.

${ }^{45}$ Tamże 70, 6, CSEL 75, 161: „Nam in fortiori aetate qui praesumit aliquatenus sine praecepto abbatis vel in ipsis infantibus sine discretione exarserit, disciplinae regulari subiaceat, quia scriptum est: Quod tibi non vis fieri, alio ne feceris", ŹM 40, 500. 
THE ROLE OF THE „ELDERS” IN THE SELECTED ANCIENT MONASTIC RULES

\section{(Summary)}

In the ancient Monastic Rules we can find various principles concerning the Community, persons and Monasteries. Among them we can also find some norms that apply to the so called „Elders" or ,seniors". They distinguish themselves from other monks, by being more advanced in the spiritual and ascetic life and because of this they are set as an example to follow for other Monks. For this reason they have rights to special respect from their fellow brothers. That is the first group of „Elders”. The other group of „Elders” contains Monks of venerable age. They occupy an important position in the monastic community and for this reason their advices, instructions, and admonishes are significant and are often treated as the legal rules. In some cases, ,the Elders” are treated as substitutes of Superiors, for example: in preaching, in giving permissions, and in rebuking their fellow brothers, as well as superiors. They are also responsible for the formation of novices. The „Elders” were to be respected and those of venerable age were dispensed from certain duties and norms of the Monastic Rule. Summarizing we can say that the role of the „Elders” in the Community was very important from all points of view. 
